\title{
Review
}

\section{Lincoln's political thought}

\author{
George Kateb \\ Cambridge, MA, Harvard University Press, 2015, xiii+236pp., \\ ISBN: 978-0674368163
}

Contemporary Political Theory (2016) 15, e33-e37. doi:10.1057/cpt.2015.35; published online 8 September 2015

This is an extremely dense book - dense not in the sense of opaque but in the fact that there is not one unnecessary word in it, nor are there any missing words: it is a model of clarity. In reading we think along with George Kateb, always in conversation with him as he is with himself and all of us with both the private and the public Lincoln. Underlying this wondrous study is a basic question, ever present in the political realm but perhaps more salient today than in the past. For Kateb, Lincoln's 'whole political life illustrates the generalization that in democratic politics, perhaps in all politics, it is nearly impossible to do the right thing for the right reasons, actually held and honestly stated' (p. xiii).

This sentence raises at least three issues about political action and beliefs that are explored throughout the book: 'nearly impossible, 'actually held,' and 'honestly stated.' The setting is a political version of the Euthyphro: Did Lincoln abolish slavery in order to preserve the Union, or did he preserve the Union in order to abolish slavery? The answer comes in what Kateb refers to as Lincoln 'single greatest sentence' (pp. 208-209) - the penultimate sentence of the Second Inaugural Address [4 March 1865]: 'Yet, if God wills that it [the war] continue until all the wealth piled by the bondsman's two hundred and fifty years of unrequited toil shall be sunk, and until every drop of blood drawn with the lash shall be paid by another drawn with the sword, as was said three thousand years ago, so still it must be said "the judgments of the Lord are true and righteous altogether"'. The citation is from Psalms 19.9; the Psalmist continues with the assertion that such judgments are 'more ... desired than gold [and] sweeter ... than honey.'

That Kateb picks out his passage at the end of his book is significant for at times he wishes, more or less explicitly, that secularism would be 'sufficient' to Lincoln's political thought. Half-way through the book he argues that Lincoln's theological references (especially in the late 1850s) were 'redundant.' (Kateb has long wrestled with religiosity, complaining in The Inner Ocean that Emerson was in some things still 'too religious.')

There are complex reasons for invoking secularity and religiosity. Central to Kateb's understanding is the fact that 'Lincoln hated slavery' (p. 97). He says as much (Speech

(C) 2016 Macmillan Publishers Ltd. 1470-8914 Contemporary Political Theory Vol. 15, 2, e33-e37 
of 10 July 1858: Collected Works [CW] (Rutgers University Press), vol. II, p. 492), but, contrary to most if not all other readings that take this as either less than true (he sometimes seemed willing to allow slavery in the South) or obvious (no one wants to be a slave), Kateb asks the key question: why did Lincoln hate slavery?

The answer has several parts. First, Lincoln thought that if one familiarized oneself with the 'chains of bondage,' one was 'preparing [one's own] limbs to wear them' [Speech of 11 September 1858]. Enslavement of blacks leads, one might say, to Rousseau's 'he who believes himself the master of others is all as much a slave as they' [Soc. Contract I.1]. Yet this assimilation of chattel slavery to political tyrannical slavery is by itself insufficient, for slavery was for Lincoln a 'monstrous injustice.'

Why? The second reason for his hatred is that he is committed first and foremost to the equality of individual rights, a commitment that rests on three tenets: nontyranny, self-government, and self-ownership (p. 99). Non-tyranny: Government is not to use people for its own ambitions; self-government: rule is to be consented to, consent being manifest in the exercise of one's rights; and self-ownership: one should not be dispossessed of the fruits of one's labor. Slavery is 'an extreme violation of all these' (p. 99). (I note here that Lincoln's argument for temperance in the 'Address to the Temperance Society,' (22 February 1842) was on the political grounds that if one were a slave to liquor, one could not be in possession of oneself, the basic prerequisite for being a good citizen.)

On what did Lincoln base his commitment to equality? Kateb is clear that he had to 'cloak his (studiously qualified) radicalism in venerable authority' (p. 104), in this case Jefferson and the Declaration of Independence. (Here Kateb agrees with Garry Wills (Lincoln at Gettysburg) - but is much better than Wills: he shows that Lincoln's privileging of the Declaration long pre-dates the Gettysburg Address.) In the reconstructed transcript of a speech given in Lewistown, IL, on 17 April 1858, Lincoln claims to be 'actuated in this contest by something higher than an anxiety for office,' namely the Declaration, which he holds asserts the equality of all (not 'none but rich men or none but white men') and furthermore that the Founders, Jefferson in particular, shared that opinion despite the fact that they continued to hold slaves (pp. 101-103; Lincoln from $C W$, vol. II, pp. 546-547 - GK cites an earlier portion). Lincoln's public justification of his commitment to equality rests, in other words, on his pretense that Jefferson, if not by his actions then by his ideas and his sentiments, was opposed to slavery. Lincoln claims historical legitimacy for what was in fact a radical claim.

What then about the Constitution, which notoriously enshrines slavery and privileges white freedom? It was a Constitution that led Thoreau to declare in 1848: 'How does it become a man to behave toward this American government today? I answer, that he cannot without disgrace be associated with it. I cannot for an instant recognize that political organization as my government which is the slave's government also' (Civil Disobedience, para. 7). And yet Lincoln did not take Thoreau's position. 
As the Constitution stood, it raised the question of what a 'right' actually is. Kateb is uncompromising: 'A right is only a right if it is both universal and absolute' (p. 107). Hence, in America the 'rights' that whites enjoyed are in fact privileges, and indeed any abridgement of a right (out of some kind of necessity) turns that right into a privilege. Lincoln's upholding of the legitimacy of the Constitution during the period from 1854-1860 must thus in part be attributed to political necessity.

What were Lincoln's hopes for the Constitution? As Kateb presents them, Lincoln appears to originally have had the hope - present in several of the Founders and several of the original states - that slavery would gradually fade away. But with the effective repeal of the Missouri Compromise by the (Stephen Douglas-authored and -sponsored) Kansas-Nebraska Act of 1854 Lincoln despairingly realizes in a private letter that "no peaceful extinction of slavery [is] in prospect for us' (p. 127; $C W$, vol. II, p. 318). I cannot resist citing some more of this letter: 'We have grown fat and lost all dread of being slaves ourselves, we have become so greedy to be masters that we call the same maxim ["that all men are created equal"] a "self-evident lie". The fourth of July has not quite dwindled away; it is still a great day - for burning fire-crackers.' Slavery has all but erased the principle on which the country was founded.

Yet Lincoln continued to have public reverence for the Constitution. Kateb here sees Lincoln as bound by his reverence for the founding document: only on occasion did the truth of the situation break through. Kateb thus reads the 'House Divided' speech (16 June 1858) as politically hamstrung (pp. 125-127): 'In sum, in the metaphor of the house divided much was compressed, waiting on time to release itself' (p. 46). (One need hardly note that Kateb rejects Henry Jaffa's contention that Lincoln was challenging Douglas from an Aristotelian philosophical position).

During the war Lincoln suspended the Constitution out of military necessity. This 'meant that the constitution that he revered was grossly injured and endured the injury of having precedents set for future presidents,' who did not always act in good faith. 'The injury of injuries that the Constitution experienced was that it was shown up as inadequate to the unprecedented emergency in which the Union faced destruction and since that time has been treated, under such cover, as inadequate for much lesser emergencies or for spurious ones' (p. 152). What Kateb finds particularly pernicious is the resultant doctrine (multiply invoked in recent decades) that a single branch of government - the executive - under conditions that it can itself determine can sovereignly exercise 'unlimited political will within national boundaries.' Kateb finds in Lincoln the inauguration of a genealogy that leads to Carl Schmitt - and Schmitt did indeed invoke Lincoln in his brief in support of Franz von Papen's declaration of dictatorial sovereignty over Prussia in 1932. Kateb writes: 'hatred of slavery and the wish to denounce race-based recognition of fundamental rights should not lead us to make light of Lincoln's suspension of those so-called rights ... It can happen, it did happen, it is happening now: if the privileges that people habitually think of as rights are suspended or abridged the painful realization grows that there actually had not been 
rights before, only undependable privileges, illusory rights that gave way under pressure' (pp. 160-161).

Kateb also notes as an aside that with Lincoln's commitment to equality came also a secondary but significant commitment to the American state. It is a matter of historical record that England and France fairly openly supported the South's cause as its victory would reduce the weight and presence of the United States on the international scene.

So the standard question in the secondary literature has been whether or not Lincoln's primary commitment was to the Union or to the end of slavery. Let me consider here Kateb's analysis of the famous letter that Lincoln wrote to Horace Greeley on 22 August 1862. Greeley had two days before published a ninepoint editorial in the New York Tribune urging Lincoln to take measures to emancipate slaves and to enforce those measures of emancipation already existent. Lincoln's response claimed that he wished only to save the Union and by any means: if this meant freeing no slaves or some slaves or all slaves, he would do what is necessary. Kateb notes, however, that while many scholars have used this letter to argue that Lincoln cared for nothing but the Union, he had already written a preliminary draft of the Emancipation Proclamation, had abolished slavery in the District of Columbia, approved a law abolishing slavery in the territories and signed the second Confiscation Act authorizing the seizure of the slaves of anyone found guilty of supporting the rebellion. (pp. 172-173; $C W$, vol. v, pp. 388-389).

Lincoln closes his letter to Greeley by distinguishing between his 'official' duty and his 'personal' wish. Kateb starts a subsequent paragraph by referring - for (I believe for) the first time - to 'President Lincoln,' Lincoln, that is, in his purely public capacity. He then suggests that Lincoln made 'an almost inhuman calculation' (p. 174), which was to retard emancipation because of military necessity. 'Perhaps,' Kateb concludes, 'if you take the perspective of a slave rather than that of a political leader, Lincoln's decision is impossible to vindicate at all. I suppose an observer must take both perspectives' (p. 174).

This maintained 'putative Constitutional correctness' and kept favor with the loyal but slave-owning border states, but these were not the most important reasons. It brought to the South (and the North) the continuation of the war toward a hoped for ultimate Union victory (a wager with God, if there ever was one) and the price that would exact - the situation that he described in the Second Inaugural with his 'greatest sentence.' In effect, Lincoln puts into political practice Rousseau's dictum about masters and slaves. He 'made it happen that those who enslaved and those who befriended the system of enslavement should get a taste of what it meant to be enslaved; not of course in the full systematic way they had enslaved others, but enough of political slavery carried to the point of actual despotism that the South could feel and the world could see' (p. 175).

Lincoln wagers with God or Providence and cannot foresee what is destined; he also believes in personal responsibility (and held the South - and the North - responsible). 
He appears to have 'two parallel systems of interpretation of the same facts' (p. 191). What is unusual about his outlook is that Lincoln was willing 'to believe that providential purpose and enlightened human judgment (including the best moral judgment) might not coincide.' This was a 'metaphysical wilderness' (p. 195). The prolongation of the war accords with the designation of providence: a retribution for the Southern embrace of slavery and the complicity of the North. Providentially the preservation of the Union was purely instrumental to ending slavery: the Union deserved to exist only if it 'undid what it should never have done' (p. 209). The war, as it was conducted and as it lasted, was retribution on a people that 'had to take seriously the principle of equality that they professed' (p. 211). Lincoln is avenger and thereby redeemer. His 'political greatness [came] with an exorbitant moral cost, even if that achievement, by some method of reasoning, exceeds in worth its cost' (p. 217). Kateb is clear that he sees both the North and the South as culpable for slavery and thus the war. He argues that while 'from 1854, Lincoln had harbored the aim of working to end slavery, no matter what it cost the country ... neither [the North nor the South was] punished enough for the incomparable moral disaster of slavery, for which both bore responsibility' (pp. 216-217); Kateb's italics).

This is a deeply thought and deeply felt book and a lesson for our times. Its originality in relation to Lincoln is that it does not rely on his death in order to excuse him from censure nor use his political realism to explain his greatness. Kateb makes the point that if Lincoln set a precedent for the justification of unconstitutional action by later executives he also 'suffered as much anguish in victory as he would in defeat' (p. 218). And Kateb reminds us that if this is the greatness of Lincoln, it is a quality sadly lacking in our times, when there is no anguish - even in defeat.

\author{
Tracy B. Strong ${ }^{\mathrm{a}, \mathrm{b}}$ \\ ${ }^{a}$ University of Southampton, Southampton SO17 1BJ, UK \\ ${ }^{\mathrm{b}}$ University of California, San Diego, La Jolla, CA 92093, USA \\ t.b.strong@soton.ac.uk; tstrong@ucsd.edu
}

